\title{
Synthesis of ZnO Nanoparticles Doped Zirconium Oxychloride by PSTA BATAN Yogyakarta Production as Photoanode Semiconduktors for Dye Sensitized Solar Cell
}

\author{
Domo Slamet*, Didik Krisdiyanto, Khamidinal \\ Chemistry Department, Faculty of Science and Technology, UIN Sunan Kalijaga Yogyakarta \\ Jl. Marsda Adisucipto No 1 Yogyakarta 55281, Indonesia. Tel. +62-274-540971, Fax. +62-274-519739. \\ *Email: domoslmt@gmail.com
}

\begin{abstract}
Slamet D, Krisdiyanto D, Khamidinal. 2017. Synthesis of ZnO Nanoparticles Doped Zirconium Oxychloride by PSTA BATAN Yogyakarta Production as Photoanode Semiconduktors for Dye Sensitized Solar Cell. Proc Internat Conf Sci Engin 1: 91-97. Dye Sensitized Solar Cell (DSSC) is a device for light conversion to be electrical energy based on the concept of semiconducting sensitivity of the wide gap. This study aims to synthesis nanoparticles of $\mathrm{ZnO}$ : $\mathrm{Zr}$ semiconductors and tested the performance of $\mathrm{ZnO}$ : $\mathrm{Zr}$ nanoparticles on the DSSC system. ZnO Doped $\mathrm{Zr}$ Nanoparticles from $\mathrm{ZrOCl}_{2} \cdot 8 \mathrm{H}_{2} \mathrm{O}$ precursor by Science and Technology Acceleration Center of National Nuclear Energy Agency (PSTA BATAN) Yogyakarta production was synthesized by gel-combustion method, and tested its performance on DSSC system. Effect of doping concentration variation $\mathrm{Zr}(0,1,3$ and 5\%) on the structure crystals and optical properties of $\mathrm{ZnO}$ studied by X-ray diffraction, infra-red spectra, and UV-Visible absorbance spectra. In this study also studied about the effect of $\mathrm{Zr}$ doping on changes in the parameters of crystal structures such as distances between fields of crystals $d_{h k l}$, crystals lattice (a and c), unit cell volume, crystallite size, microstrain $(\varepsilon)$, dislocation density $(\delta)$, and the textural coefficient $T C_{\mathfrak{R} R l}$. The synthesized nanoparticles meet the criteria 3-dimensional nanostructure of hexagonal wurtzite crystals. Uptake $\mathrm{ZnO}$ infrared radiation shows an increase in intensity as well shift in wave number 610 - 400 due to doping $\mathrm{Zr}$. Doping $\mathrm{Zr}$ also influences the electronic structure of semiconductors characterized by the change of bandgap energy from 3,10-3,05 eV. Semiconductor performance test nanoparticles on the DSSC system showed a $1 \% \mathrm{Zr}$ doping concentration increasing the voltage by $174 \mathrm{mV}$ and the stability of the solar cell than the cell $\mathrm{ZnO}$ solar without doping that produces a voltage of $128 \mathrm{mV}$.
\end{abstract}

Keywords: Semiconductor, gel-combustion method, $\mathrm{ZnO}$

\section{INTRODUCTION}

The world's energy needs are now at a very worrying condition. Worldwide energy use is currently about 14 terawatts, and by the end of the 21st Century, it is possible to reach 50 terawatts (Dresselhaus, et al., 2005). Approximately $80 \%$ of the energy needs are still filled by fossil fuels that have limited resources and have emissions that are not environmentally friendly. Quoting David Bower's statement, "We do not inherit the earth from our ancestors, but we borrow it from our children." So it takes a diversion on renewable energy sources. Renewable sources based on earth energy such as hydroelectricity, wind, geothermal, biomass and others will certainly not be enough to meet world energy consumption (Apelian, 2007).

The energy source for solar cells is abundant and renewed is one reason for the development of this solar cell. According to Yuliarto (2006), solar energy supply from sunlight is accepted if the surface of the earth is very large that reaches $3 \times 10^{24}$ joules per year. That amount of energy is equivalent to 10,000 times the energy consumption worldwide today. In other words, covering $0.1 \%$ of the Earth's surface with a solar cell device that has a $10 \%$ efficiency is capable of covering the energy needs of the entire world today (Hardian, et al., 2010).

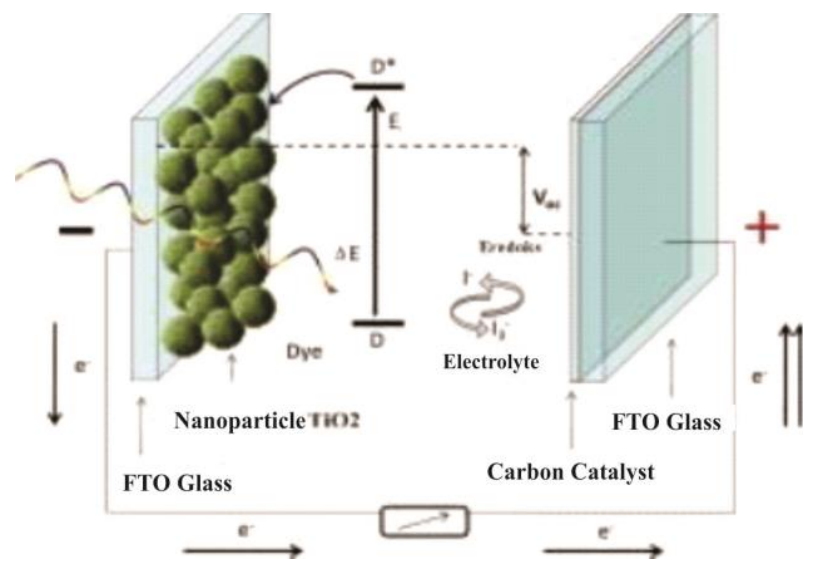

Figure 1. Scheme and working principle of Dye Sensitized Solar Cell (DSSC).

Various things have been done to modify the components of this dye-synthesized solar cell. DSSC is a solar cell composed of several components where it is possible to do modifications in an attempt to improve the performance of these solar cells. Amended modifications include dye replacement (Khuzaifah, 2014), redox electrolyte replacement (Hardian et al., 2010), variations to semiconductors (Parthiban et al, 2015), to the various methods used for DSSC fabrication. 
Based on the above, this research is focused on semiconductor modification which is the main component of DSSC using $\mathrm{ZnO}$ : $\mathrm{Zr}$, where in general the semiconductor used is $\mathrm{TiO}_{2}$ which isindirect bandgap type semiconductor. $\mathrm{ZnO}$ is a semiconductor type of direct bandgap that is easily available in the market with a relatively cheap price, and has bandgap $3.37 \mathrm{eV}$ (Coleman \& Jagadish, 2006) so it is transparent at room temperature and absorbs light at the wavelength region UV and blue with the transfer capability electrons are faster than $\mathrm{TiO}_{2}$ if the gap energy is equal. $\mathrm{ZnO}$ binds exciton energy of $60 \mathrm{MeV}$ so that $\mathrm{ZnO}$ has better electron transfer capability than $\mathrm{TiO}_{2}$ which only exciton energy binding of less than $30 \mathrm{MeV}$. However, the use of $\mathrm{ZnO}$ is still constrained by unfavorable chemical stability, so it needs modification as an effort to improve the quality of $\mathrm{ZnO}$.

The study of $\mathrm{ZnO}$ doped $\mathrm{Zr}$ has been done by several researchers, but in this study zirconium used comes from zirconium oxychloride of zircon sand processing by PSTA BATAN Yogyakarta. Based on information from PSTA BATAN Yogyakarta, the use of zirconium oxychloride produced of the zircon sand extraction process by the agency has not been done as a doping precursor (Poernomo, 2012). Zirconium includes elements of transition, atomic number 40, and relative mass of 91.22. The zirconium metal is grayed out very hard, melt at $1852^{\circ} \mathrm{C}$. So through the properties of zirconium is expected to improve the stability and chemical properties of $\mathrm{ZnO}$ physics through doping way.

Along with the development of the era of nanotechnology, $\mathrm{ZnO}$ metal oxide synthesis has also been much in the formation of nanoscale materials. This is because the nanoscale material will provide better electronic properties and optical properties compared to bulk materials (Zhao, et al., 2007). Various methods are used to produce high-quality $\mathrm{ZnO}$, so that the size and shape of $\mathrm{ZnO}$ can be directed to the nanoscale so that it can be applied as an optoelectronic device. According to previous research, to improve the quality of $\mathrm{ZnO}$ can be done by doping. To date, $\mathrm{ZnO}$ has been doped with $\mathrm{Tb}$ (Yang, et al. 2008), Gd (Murmu, et al., 2009), Yb (Jiang, et al., 2010), Ce (George, et al., 2011), Eu (Badalawa, et al., 2011), Er (Jang, et al., 2011) and Nd (Xian \& Li, et al., 2012).

$\mathrm{ZnO}$ nano synthesis method can be done in various ways, but the method of phase synthesis of the solution is considered more economical and can be applied in a wider scale. Solution phase synthesis methods such as sol-gel, auto-combustion, hydrothermal, electro deposition and chemical bath deposition (CBD) are becoming more intensive methods developed by researchers. Amongst several methods the autocombustion method becomes an attractive option because of various advantages such as simple and low cost (Elilarassi, et al., 2010). The auto-combustion method provides advantages such as reaction stoichiometry can be controlled at the molecular level, homogeneity and purity of high-synthesized material (Khan, et al., 2013).

This study will examine the effect of doping $\mathrm{Zr}$ variation on $\mathrm{ZnO}$ crystal structure, optical properties and application test on $\mathrm{ZnO}: \mathrm{Zr}$ in DSSC. The main objective of this research is to obtain new semiconductor material for photo anode solar cell synthesized Tacca Palmata dye extract.

\section{MATERIALS AND METHODS}

Synthesis of Nanoparticles Semiconductor $\mathrm{ZnO}$ : $\mathrm{Zr}$ by Gel-Combustion Method (Khan et al., 2013).

The zinc acetate solution in hydrate $\left(\mathrm{Zn}\left(\mathrm{CH}_{3} \mathrm{COO}\right)_{2}, 2 \mathrm{H}_{2} \mathrm{O}\right)$ was dissolved in $50 \mathrm{~mL}$ distilled water on a $100 \mathrm{~mL}$ cup glass to form a $\mathrm{ZnO}$ solution, with the solubility set at $0.3 \mathrm{~mol} / \mathrm{Liter}$. Then added citric acid $\left(\mathrm{C}_{6} \mathrm{H}_{7} \mathrm{O}_{8}\right) \cdot \mathrm{H}_{2} \mathrm{O}$ of $0.3 \mathrm{~mol} / \mathrm{L}$. citric acid $\left(\mathrm{C}_{6} \mathrm{H}_{7} \mathrm{O}_{2}\right) \cdot \mathrm{H}_{2} \mathrm{O}$. The mixed solution was then added zirconia dichloride solution $\left(\mathrm{ZrOCl}_{2}\right)$ with variation concentration $0 \%, 1 \%, 2 \%, 3 \%$ and $4 \%$ to concentration $\left(\mathrm{Zn}\left(\mathrm{CH}_{3} \mathrm{COO}\right)_{2}, 2 \mathrm{H}_{2} \mathrm{O}\right)$.

The solution is stirred slowly for two hours with a maximum temperature of $120^{\circ} \mathrm{C}$, the heating is done gradually to obtain a uniform solution and to evaporate the solvent. The gel phase formed is inserted into the porcelain crust, then burned using a furnace.

The conditioning temperature of the furnace is carried out at a temperature of $200^{\circ} \mathrm{C}$ for 1 hour, increased to a maximum temperature of $500^{\circ} \mathrm{C}$ for 3 hours. Then increased gradually until it reaches a maximum temperature of $700^{\circ} \mathrm{C}$ for 3 hours, and after reaching $700^{\circ} \mathrm{C}$ the temperature is slowly lowered to room temperature. Samples were analyzed by X-ray diffraction and FT-IR.

\section{ZnO:Zr Semiconductor Deposition on ITO glass substrate by doctor blade method.}

The $\mathrm{ZnO}$ : $\mathrm{Zr}$ Semiconductor layer is made by the doctor blade method deposited on the ITO glass substrate. The glass substrate used is first cleaned with ethanol while vibrated with an ultrassonic cleaner for 5 minutes each, then rinsed with aquades to remove the oil content and impurities attached to the substrate.

As much as 1 gram the synthesized result of $\mathrm{ZnO}: \mathrm{Zr}$ and $1 \mathrm{~mL}$ PEG 400 is mixed and crushed porcelain, to obtain a homogeneous paste. Before the paste is dripped on ITO glass, the first sought conductive part is then given a schotlite barrier and a rectangular pattern is created leaving space $1.5 \times 1.8 \mathrm{~cm}$. Furthermore, above the area, the distribution of the paste is evenly distributed using a glass rod.

The samples were heated at temperatures of $100^{\circ} \mathrm{C}$ and $400^{\circ} \mathrm{C}$ each for 1 hour to eliminate PEG 400 and increase the interaction between particles and ITO glass physically. After 1 hour of heating at $400^{\circ} \mathrm{C}$, furnace temperature is lowered to room temperature. The 
samples were then analyzed by UV-Vis reflectance spectrophotometer

\section{Fabrication of dye sensitized solar cell.}

a. Preparation of dye solution from fruit extract of Tacca Palmata as dye sensitizer (Syafinar et al., 2015)

b. Electrolyte preparation from electrolyte solution of redox iodine pair, Iodide (I- / I3-), and PEG 1000 in water solvent and chloroform.

c. Preparation of $\mathrm{ZnO}: \mathrm{Zr}(0,1,3$, and 5\%) pastes from ZnO: Zr nanoparticles mixed with PEG 400.

d. Preparation working electrode from $\mathrm{ZnO}$ : $\mathrm{Zr}(0,1,3$, and $5 \%$ ) pastes is deposited on glass ITO (Indium Tin-Oxide) glass by doctor blade method.

e. Preparation the comparative electrode is a carbon layer deposited on an ITO (Indium Tin Oxide) glass substrate.

f. Preparation of open circuit voltage characterization test equipment (Voc) and DSSC stability.

g. DSSC sandwich making (with bearing) and open circuit voltage characterization test (Voc) and stability of DSSC that have been made.

\section{RESULTS AND DISCUSSION}

\section{Structural analysis using $X$-ray diffractometer.}

Characterization of $\mathrm{ZnO}: \mathrm{Zr}$ nanoparticles was carried out by X-ray diffraction method, the diffractogram result of the sample analysis is presented in Figure 2. The diffraction showed that the sample tested was $\mathrm{ZnO}$ with a hexagonal crystal system (wurtzite) shown by diffraction peaks in the plane $: \mathrm{d}_{001} ; \mathrm{d}_{002} ; \mathrm{d}_{101} ; \mathrm{d}_{102}$; $\mathrm{d}_{110} ; \mathrm{d}_{103} ; \mathrm{d}_{200} ; \mathrm{d}_{112} ; \mathrm{d}_{201} ; \mathrm{d}_{004}$ dan $\mathrm{d}_{202}$. The XRD data is paired with standard $\mathrm{ZnO}$ data (JCPDS No. 361451).

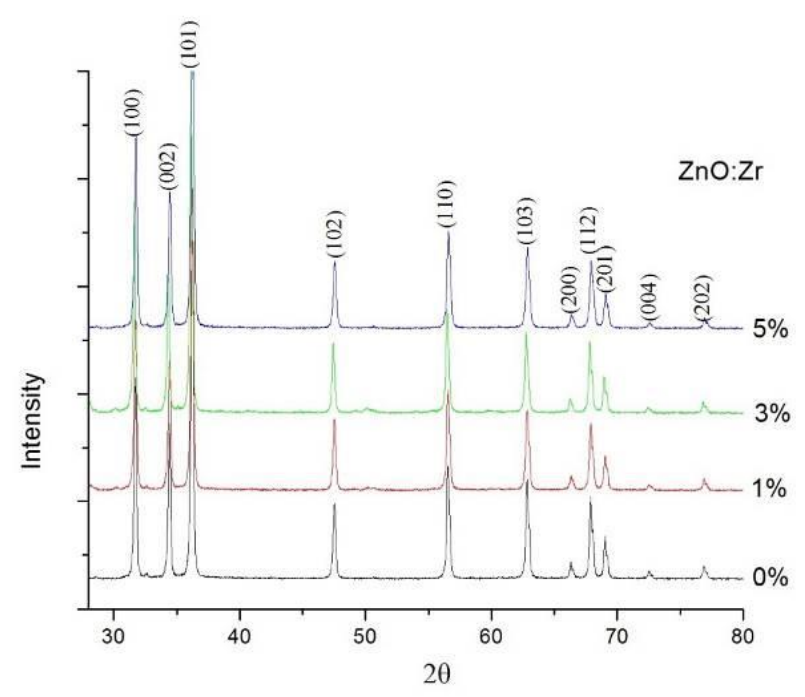

Figure 2. Diffractogram of $\mathrm{ZnO}: \mathrm{Zr}$ nanoparticles with doping concentration variations of $0,1,3$ and $5 \%$.
The effect of $\mathrm{Zr}$ doping on the $\mathrm{ZnO}$ crystal structure is indicated by the diffraction peak shift presented in Fig. 3. However, detected diffraction peaks at doping levels of 1,3 and $5 \%$ at an angle of $2 \theta$ : $28,158^{\circ}, 30,10^{\circ} ; 32,612^{\circ} ; 50,33^{\circ}$ which is the peak of impurities. Based on matching using standard data, the peak at 20: $28,158^{\circ}$ is $\mathrm{ZrO}_{2}$ monoclinic phase (JCPDS37-1484). While peak at angle 20: $30,10^{\circ} ; 32,612^{\circ} ; 50,33^{\circ}$ tetragonal phase (JCPDS-501089).

The peaks of detected impurities have relatively low intensity compared to the peak intensity of $\mathrm{ZnO}$, thus up to $5 \%$ of the sample doping level is still dominated by the $\mathrm{ZnO}$ phase. The intensity of the diffraction peak $\mathrm{ZrO}_{2}$ is higher at the doping level of $\mathrm{Zr} 3$ and $5 \%$. This occurs in the presence of an excess of $\mathrm{Zr}^{4+}$ ions in $\mathrm{ZnO}: \mathrm{Zr}$ solution that exceeds the limit of its solubility during wet reaction using water, resulting in the decomposition of the material in annealing and sintering processes. The detection of other diffraction peaks in the synthesis of $\mathrm{Cu}$ nanoparticles in $\mathrm{Cu}$ doping has been reported by Muchtar et al. (2012).

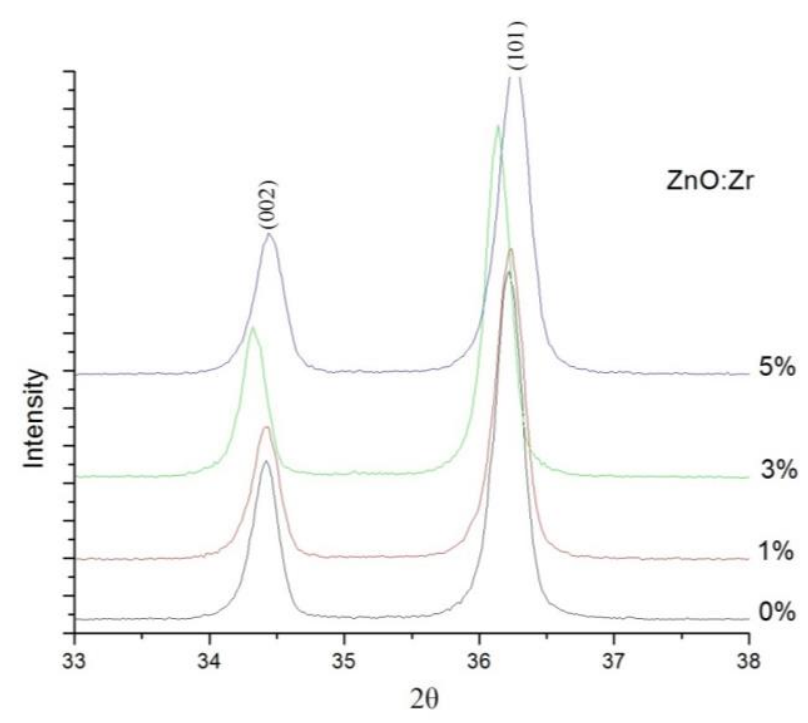

Figure 3. Magnification of field diffraction peaks $d_{002}$ and $d_{192}$

The single phase of $\mathrm{ZnO}$ doping $\mathrm{Zr}$ nanoparticles was obtained by Khan et al. (2013) using $\mathrm{Zn}\left(\mathrm{NO}_{3}\right)_{2} \cdot 4 \mathrm{H}_{2} \mathrm{O}$ reagent with gel-combustion synthesis method as used in this study. According to Murtaza et al. (2014) the phase of impurity appears to be estimated that $\mathrm{Zr}$ ions migrate to the $\mathrm{ZnO}$ matrix and occupy the defect position, ie the tetragonal position because the tetrahedral coordination is not possible to occupy by the ion if the doping concentration exceeds its solubility limit. 
Table 1. The result of calculation of crystallite size (D), lattice parameter, c / a ratio, unit cell volume (V), textural coefficient (TC), dislocation density $(\delta)$, and micro strain $(\varepsilon)$.

\begin{tabular}{|c|c|c|c|c|c|c|c|c|}
\hline \multirow{2}{*}{$\begin{array}{l}{[\mathrm{Zr}]} \\
\%\end{array}$} & \multirow{2}{*}{$\begin{array}{l}\text { Crystalit } \\
\text { size (nm) }\end{array}$} & \multicolumn{2}{|c|}{ Lattice parameter } & \multirow{2}{*}{$\mathbf{c} / \mathbf{a}$} & \multirow{2}{*}{$\mathbf{V}\left(\mathbb{A}^{3}\right)$} & \multirow{2}{*}{$T C_{(002)}$} & \multirow{2}{*}{$\begin{array}{l}\delta 10^{11} \\
\text { lines } / \mathrm{cm}^{2}\end{array}$} & \multirow{2}{*}{$\varepsilon 10^{-3}$} \\
\hline & & $\mathbf{a}(\hat{A})$ & $\mathbf{b}(\AA)$ & & & & & \\
\hline 0 & 31,87 & 3,253 & 5,207 & 1,601 & 47,72 & 0,25 & 0,984 & 0,7 \\
\hline 1 & 26,36 & 3,249 & 5,201 & 1,601 & 47,55 & 0,33 & 0,823 & 3,167 \\
\hline 3 & 29,80 & 3,253 & 5,205 & 1,600 & 47,70 & 0,33 & 0,7616 & 1,58 \\
\hline 5 & 38,07 & 3,264 & 5,220 & 1,599 & 48,16 & 0,36 & 0,5566 & 4,014 \\
\hline
\end{tabular}

Based on XRD data, we can determine the lattice parameters (equation 1), unit cell volume (equation 2), crystallite size (equation 3), microstrain (equation 3), and dislocation density (equation 4) $\mathrm{ZnO}$ determined from the diffraction field as presented in table 1, (Lupan, et al., 2010; William and Hall, 1953; Nehru, et al. 2012). The presence of $\mathrm{Zr}$ doping concentrations of 1 and 3\% leads to decreased crystallite size and unit cell volume. It is presumed that $\mathrm{Zr}$ precursors in the solution behave as a catalyst that decreases the nucleating energy of $\mathrm{ZnO}$ nucleation. The formation of the solution through saturation in the system becomes faster by the presence of temperature function, so quickly formed the precipitate.

$$
\begin{aligned}
& \frac{1}{d_{h k l}^{2}}=\frac{4}{3}\left(\frac{h^{2}+h k+k^{2}}{a^{2}}\right)+\frac{a^{2}}{c^{2}} \\
& V=\frac{\sqrt[4]{3} a^{2} c}{2}=0,866 a^{2} c \\
& \beta \cos \theta=\frac{K \lambda}{D}+4 \varepsilon \sin \theta
\end{aligned}
$$

$\delta=\frac{1}{D^{2}}$

According to Wang (2003) $\mathrm{ZnO}$ nucleation growth behavior can be directed in the form of nanocages by decreasing the activation energy of nucleation growth using $\mathrm{Au}$ metal catalyst so that $\mathrm{ZnO}$ nanocages can be produced with 10-30 nm crystallite size. The alleged $\mathrm{Zr}$ metal behaves as a catalyst amplified by the detection of diffraction peaks at dopant 1 and $3 \%$ levels corresponding to the data standard $\mathrm{ZrO}_{2}$. The success of $1-3 \% \mathrm{Zr}$ doping concentrations in the $\mathrm{ZnO}$ crystalline system can be explained by the shift in the diffraction field at $2 \theta$ smaller than the $\mathrm{ZnO}$ diffraction angle without doping. This may be due to the ion substitution $\mathrm{Zn}^{2+}(74 \mathrm{pm})$ by ion $\mathrm{Zr}^{4+}(84 \mathrm{pm})$ having a larger radius, the lattice parameter values of 1 and $3 \%$ doping reinforce this presumption because there is relatively no significant change in the values of a and c compared to the standard data of the $\mathrm{ZnO}$ wurtzite hexagonal structure.

Khan et al. (2013) and Murtaza et al. (2014) also gained a shift in the position of the peaks of the diffraction field to a smaller value of $2 \theta$ dengan with an increase in $\mathrm{Zr}$ concentration, and the researchers attributed it to the placement of $\mathrm{Zr}^{4+}$ ions in the $\mathrm{Zn}$ position on the $\mathrm{ZnO}$ crystal lattice. Khan et al. (2013) states that $\mathrm{Zr}$ ions tend to occupy $\mathrm{Zn}$ positions on the $\mathrm{ZnO}$ lattice rather than the interstitial position. However, at a 5\% doping rate there is an increase in unit cell volume and particle size, it is suspected that $\mathrm{Zr}$ has been successfully doped on a $\mathrm{ZnO}$ crystal system where $\mathrm{Zr}$ ion occupies an interstitial position. This is supported by a 5\% doping lattice parameter indicating an increase in values of a and $\mathrm{c}$, one of the characteristics of doping success is the expansion of lattice parameters due to the presence of interstitial metal ions with a greater radius than $\mathrm{Zn}$.

The result of the calculation of the textual coefficient $\left(T C_{(002)}\right)$ uses equation 5 based on the XRD data of $\mathrm{ZnO}$ : $\mathrm{Zr}$ doping $0,1,3$ and $5 \%$ are presented in table 1 . Based on the data, the presence of dopant $\mathrm{Zr}$ has an effect on the increase of textural coefficient value for the plane (002), along with the increasing doping concentration also the value of $T C_{(002)}$. While the value of TC for other fields there are changes that are not erratic. This shows that $\mathrm{Zr}$ doping affects the dominant growth of $\mathrm{ZnO}$ crystals in vertical direction (c-axis) which is non-polar.

$T C(h k l)=\frac{I(h k l) / I_{0}(h k l)}{N^{-1} \Sigma_{n} I(h k l) / I_{0}(h k l)}$

(Caglar, dkk., 2006).

The thermodynamically increasing growth of $\mathrm{ZnO}$ crystals in the (002) plane increases the stability of $\mathrm{ZnO}$ nanoparticles because the (002) plane consists of oxygen and zinc atoms of comparable amounts (Kim et al. 2010). However, there is a possibility of growth dominance in other fields by the presence of doping $\mathrm{Zr}$ which influences the chance of the direction of crystal growth in other fields.

\section{Infrared Radiation Absorption Analysis (FTIR)}

According to Coleman and Jagadish (2006), $\mathrm{ZnO}$ absorbs infrared radiation at wave numbers $437 \mathrm{~cm}^{-1}$. The absorption of $\mathrm{ZnO}$ : $\mathrm{Zr}$ functioning groups of $0,1,3$ and 5\% can be determined by FTIR spectra measured from 4000 to $400 \mathrm{~cm}^{-1}$ is presented in figure 4 .

The high intensity and wider absorption read in the $610-400 \mathrm{~cm}^{-1}$ region is the absorption of the $\mathrm{Zn}-\mathrm{O}$ bond (Vigneshwaran, et al., 2006). While the detection of uptake with relatively low intensity in the area of 1600 $1500 \mathrm{~cm}^{-1}, 1000-1100 \mathrm{~cm}^{-1}$ and $750 \mathrm{~cm}^{-1}$ allegedly derived from chloride (C-X) ie compounds used as metal precursors. The widening peak in the region 3440 $\mathrm{cm}^{-1}$ is the uptake of $\mathrm{H}_{2} \mathrm{O}$ and the carboxylates derived 
from the precursor, this indicates that the water is adsorbed on the surface of the nanoparticles. Other absorptions present at 2300-2930 $\mathrm{cm}^{-1}$ and $1300-1480$ $\mathrm{cm}^{-1}$ are possible due to the vibration of $\mathrm{C}-\mathrm{H}$ propagation from fuel (citric acid) in the synthesis process. Absorption peaks in 900 and $1620 \mathrm{~cm}^{-1}$ are suspected due to overlapping of the peak-shifting vibration of $-\mathrm{OH}$ with $\mathrm{ZnO}$ peak as a result of water adsorption on the surface of $\mathrm{ZnO}$ (Khan, et al., 2013).

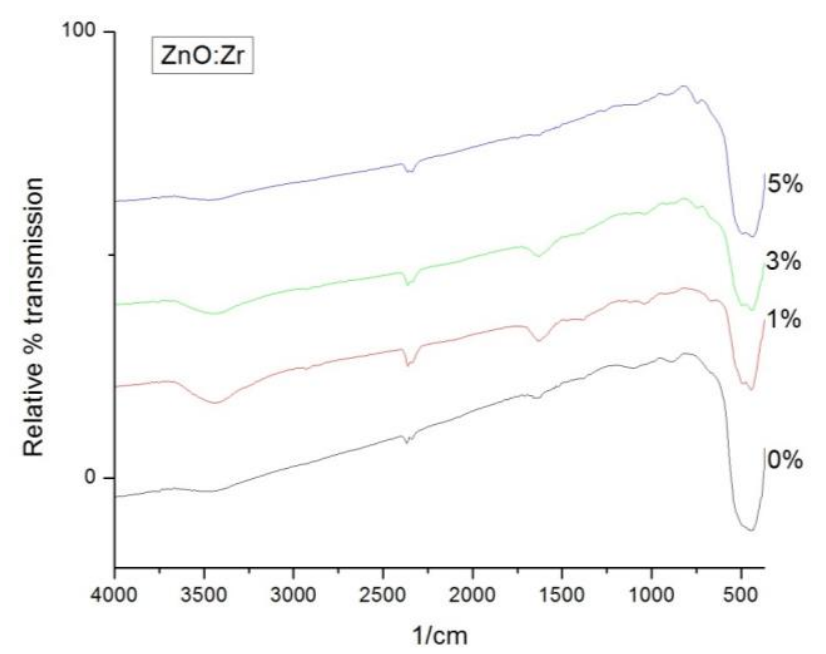

Figure 4. $\mathrm{ZnO}: \mathrm{Zr}$ FTIR spectra $(0,1,3$ dan 5\%).

The presence of peak shift and infrared absorption, allegedly occurs due to $\mathrm{Zr}$ ions that replace the $\mathrm{Zn}$ position and enter the $\mathrm{ZnO}$ structure. So it affects the length of the bonds between atoms in the wurtzite structure. Therefore, the synthetic material can be strongly suspected to be a hexagonal material wurtzite $\mathrm{ZnO}: \mathrm{Zr}$.

\section{Energy Band Gap ZnO: Zr 0, 1, 3, and 5\%.}

The bandwidth width of the band gap in a direct band gap type semiconductor can be determined based on the relationship between $\alpha$ (absorption coefficient) and $\mathrm{v}$ (light velocity), especially in photon energy adjacent to the band value of semiconductor energy. In the energy range the absorption coefficient satisfies the equation:

$$
[\alpha \mathrm{hv}]^{2}=\mathrm{A}(\mathrm{hv}-\mathrm{Eg})
$$

(Khan, dkk. 2013)

Based on Figure 5. we can know the band gap energy for each sample, ie $3.10 \mathrm{eV}$ for $\mathrm{ZnO}$ : Zop doping 0\%, $3.059 \mathrm{eV}$ for $\mathrm{ZnO}$ : $\mathrm{Zr}$ dop $1 \%, 3.057 \mathrm{eV}$ for $\mathrm{ZnO}: \mathrm{Zr}$ dop 3\%, and 3, 05 for $\mathrm{ZnO}$ : $\mathrm{Zr}$ dop $5 \%$.
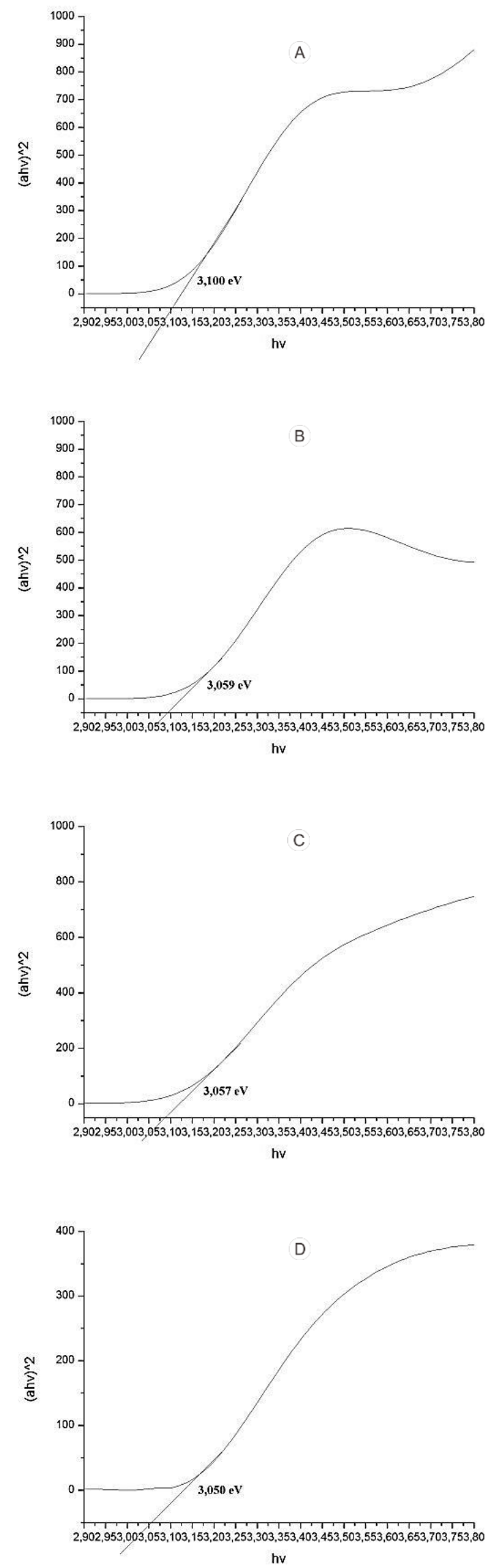

Figure 5. The relationship graph $(\boldsymbol{\alpha} \boldsymbol{h} v)^{\mathrm{2}}$ to hv. $\mathrm{ZnO}$ : (A) $\mathrm{Zr}$ doping $0 \%$, (B) $\mathrm{ZnO}$ : $\mathrm{Zr}$ doping $1 \%$, (C) $\mathrm{ZnO}$ : Zop doping 3\%, and (D) $\mathrm{ZnO}: \mathrm{Zr}$ doping $5 \%$. 
In general, the four samples have different electronic properties with bulk $\mathrm{ZnO}$ where $\mathrm{ZnO}$ with the size of the weld has a band gap energy in the range of $3.37 \mathrm{eV}$. This decrease of bandgap energy occurs due to the decrease of crystal size from large scale to nanometer range.

The effects of quantum confinement can be characterized by a shift in the bandwidth gap of nanometer-scale materials with lower geometric dimensions than the material in the scale (Chen, et al., 2006). Material with nanometer size has a high surface to volume ratio so greatly affect the optical and electronic properties. As the increase in doping concentration indicates a decline in the bandgap energy value, this is because $\mathrm{Zr}$ becomes a ribbon donor between the valence band and the $\mathrm{ZnO}$ conduction band.

\section{Test application of $\mathrm{ZnO}: \mathrm{Zr}$ nanoparticles as photoanoda semiconductor in DSSC.}

The result of the voltage measurement is presented in table 2 which is done in dark condition with the halogen lamp beam $2 \mathrm{watt} / \mathrm{cm}^{2}$. The solar cell system is said to die if the current generated by the system when the open circuit voltage (Voc) is zero. In DSSC solar cells, means that in the system there is no electron flow from the excited state of the dye to the $\mathrm{ZnO}$ : $\mathrm{Zr}$ conduction band which can produce an electric current. This can happen because there is no bond between the dye and $\mathrm{ZnO}: \mathrm{Zr}$ so that the electron injection process becomes difficult.

The solar cell system can also be said to die due to the shortening of the system due to direct contact of the working electrode and the opposing electrode. This can happen by two possibilities:

1. If the electrolyte solution is not evenly distributed over the entire contact surface of the working electrode - the counter electrode,

2. If the electrolyte solution is too diffused throughout the working electrode surface and the opposing electrode (not just the contact area), the voltage regulation becomes difficult as it becomes unstable, as well as the read current (Kartini, et al., 2008).

Table 2. The value of voltage test (Voc) DSSC based $\mathrm{ZnO}: \mathrm{Zr}$.

\begin{tabular}{crrrrrr}
\hline \multirow{2}{*}{ DSSC } & \multicolumn{6}{c}{ Times (min) } \\
\cline { 2 - 7 } & $\mathbf{1 0}$ & $\mathbf{2 0}$ & $\mathbf{3 0}$ & $\mathbf{4 0}$ & $\mathbf{5 0}$ & $\mathbf{6 0}$ \\
\hline $0 \%$ & $128 \mathrm{mV}$ & $125 \mathrm{mV}$ & $123 \mathrm{mV}$ & $120 \mathrm{mV}$ & $119 \mathrm{mV}$ & $110 \mathrm{mV}$ \\
$1 \%$ & $174 \mathrm{mV}$ & $172 \mathrm{mV}$ & $172 \mathrm{mV}$ & $167 \mathrm{mV}$ & $165 \mathrm{mV}$ & $161 \mathrm{mV}$ \\
$3 \%$ & $111 \mathrm{mV}$ & $108 \mathrm{mV}$ & $107 \mathrm{mV}$ & $101 \mathrm{mV}$ & $98 \mathrm{mV}$ & $90 \mathrm{mV}$ \\
$5 \%$ & $80 \mathrm{mV}$ & $78 \mathrm{mV}$ & $70 \mathrm{mV}$ & $69 \mathrm{mV}$ & $65 \mathrm{mV}$ & $53 \mathrm{mV}$ \\
\hline
\end{tabular}

The effect of $\mathrm{Zr}$ concentration on $\mathrm{ZnO}$ semiconductors on the performance of solar cells is presented in Table 2. Quantitatively all devices provide photovoltaic effects. Based on the magnitude of open circuit voltage (Voc) at the $1 \% \mathrm{Zr}$ doping level yields the greatest value, this is made possible by the decrease of crystallite size so that the quantity of the dyestuff bond with the semiconductor is more. Larger density or microstrain dislocation than $\mathrm{ZnO}$ without dopant has an impact on increasing the active side of the material. However, at the doping level of 3 and $5 \%$ there is a decrease in the resulting voltage value compared to the $1 \%$ doping level, based on the crystallite size approach at 3 and 5 doping levels there is an increase in crystallite size and smaller dislocation density and microstrain values, which occurs between the dye and $\mathrm{ZnO}: \mathrm{Zr}$ is less than the $1 \%$ doping rate.

Based on the study of optical properties on the performance of solar cells, should the band gap energy have a significant effect because it is associated with a smaller bandgap energy then electrons should be easier and faster injected. Based on the study of the stability of solar cells also obtained that the highest stability obtained in solar cells with semiconductors $\mathrm{ZnO}$ : $\mathrm{Zr} 1 \%$ and $3 \%$. Detection of an increasingly stronger impurity phase along with increased doping is thought to interfere with the performance of solar cells resulting in a decrease in open circuit voltage, because with the impurity causing uneven band gap distribution energy.

\section{CONCLUSIONS}

$\mathrm{ZnO}: \mathrm{Zr}$ Nanomaterials: Three-dimensional has been successfully synthesized via gel-combustion method using zinc dihydrate acetate reagents, zirconia dichloride and citric acid. Analysis of crystal structure characteristics showed a single-phase wurtzite material at a $0 \%$ doping rate. On top of the doping concentration there are three phases: wurtzite $(\mathrm{ZnO})$, monoclinic and tetragonal $\left(\mathrm{ZrO}_{2}\right)$. The resulting samples showed similarity of lattice parameter values with standard data, crystal size between 26 - $38 \mathrm{~nm}$, and along with increasing concentration showed increased crystal growth in the 002 plane.

Doping $\mathrm{Zr}$ effect on the FTIR spectra shown by the widening and shift of the functional group absorption peak. Analysis of UV-visible absorption data shows that $\mathrm{Zr}$ doping affects the gap energy of $\mathrm{ZnO}$, as for the value obtained between 3,100-3,050 eV. The application test on the DSSC shows the highest stress and stability values obtained by sampling with $1 \%$ doping.

\section{REFERENCES}

Apelian, D. 2007. Looking Beyond the Last 50 Years: The Future of Materials Science and Engineering. Overview. JOM.

Badalawa, W. Matsui, H. et al. 2011. Correlation between structural and luminescent properties of $\mathbf{E u}^{3+}$-doped $\mathrm{ZnO}$ epitaxial layers. Journal of applied physics. 109. 053502-7.

Caglar, M. Caglar, Y. and Ilican, S. 2006. The Determination of The Thickness and Optical Constants of the ZnO Crystalline Thin Film by Using Envelope Method. J. Optoelectron. Adv. Mater. 8. 1410-1413.

Chen, C. W. Chen K. H. et al. 2006. Anomalous Blueshift in Emission Spectra of $\mathrm{ZnO}$ Nanorods with Sizes beyond Quantum Confinement Regime. App, Phys. Lett. 88. 1905119053. 
Coleman, V. A. and Jagadish, C. 2006. Basic Properties and Applications of ZnO. Department of Electronic Materials Engineering. Research School of Physical Sciences and Engineering. The Australian National University. Canberra. ACT 0200. Australia.

Dresselhaus, M.S. Crabtree, G.W. and Buchanan, M.V. 2005. Addressing Energy Challenges Through Advanced Materials. MRS Bulletin. 518-524.

Elilarassi, R. and Chandrasekaran, G. (2010). Synthesis and optical properties of Ni-doped zinc oxide nanoparticles for optoelectronic. Applications Optoelectron. Lett. 6. 6.

George, A. Sharma, SK. et al. 2011. Detailed of X-ray diffraction and photoluminescence studies of $\mathrm{Ce}$ doped $\mathrm{ZnO}$ nanocrystals. Journal of Alloys and Compounds. 509. 594-46.

Hardian, A., Mudzakir, A., and Sumarna, O. 2010. Sintesis dan Karakterisasi Kristal Cair Ionik Berbasis Garam Fattty Imidazolinium sebagai Elektrolit Redoks pada Sel Surya Tersensitisasi Zat Warna. ISSN 2087-7412. 1. 7-16.

Jang, Y. R. Yoo, K. H. et al. 2011. 1.54 um emission mechanism of Er-doped zinc oxide thin films. Applied Surface Science. 257. 2822-4.

Jiang, N. Ye, S. and Qiu, JR. 2010. Electron energy-loss spectroscopy study of $\mathrm{Yb}$ doped ZnO. Journal of Applied Physics. 108(083535):1-4.

Kartini, I. Wahyuningsih, S. et al. 2008. Ekstrak Klorofil Alga Sebagai Sensitizer Sel Surya Titania Tersensitisasi Pigmen Alga (TIPA). Seminar Hasil Penelitian Klaster Sains dan Teknologi. LPPM UGM.

Khan, I. Khan, S. et al. 2013. Structural and optical properties of gel-combustion synthesized $\mathrm{Zr}$ doped $\mathrm{ZnO}$ nanoparticles. Elsevier. Optical Materials. 35. 1189-1193.

Khuzaifah, S. 2014. Karakteristik Absorpsi Ekstrak Krokot (Portulaca Oleracea L.) Sebagai Sensitiser Alami untuk DyeSensitized Solar Cell (DSSC). Skripsi. Program Studi Kimia. UIN Sunan Kalijaga. Yogyakarta.

Kim, K. S. Jeong, H. Jeong, M. S. and Jung, G. Y. 2010. Polymer Templated Hydrothermal Growth of Vertically Aligned Single Crystal ZnO Nanorods and Morphological Transformations Using structural Polarity. Adv. Funct. Mater. 20. 3055-3065.

Lupan, Z. Guerin, V. M. et al. 2010. Well-aligned Arrays of Vertically Oriented $\mathrm{ZnO}$ Nanowires Electrodeposited on ITOcoated glass Their Integration in Dye Sensitized Solar Cells. J. Photochem. Photobiol. A. 215. 65-73.
Muchtar, M. Munisa, L. and Saleh, R. 2012. Co-Precipitation Synthesis and Characterization of Nanocrystalline Zinc Oxide Particles Doped with $\mathrm{Cu}^{2+}$ Ions. Materials Sciences and Aplications. 3. 543-551.

Murmu, P. P. Kennedy, JV. et al. 2009. Compositional and structural study of $\mathrm{Gd}$ implanted $\mathrm{ZnO}$ films. Melville. American Institute of Physics. 1151. 185-8.

Murtaza, G. Ahmad, R. et al. 2014. Structural and Magnetic Studies on $\mathrm{Zr}$ doped $\mathrm{ZnO}$ Diluted Magnetic Semiconductor. Elsevier. Current Applied Physics. 14. 176-181.

Nehru, L. C. Umadevi, M. and Sanjeeviraja, C. 2012. Studies on Structural, Optical and Electrical Properties of $\mathrm{ZnO}$ Thin Films Prepared by the Spray Pyrolysis Method. International Journal of Materials Engineering. 02. 12-17.

Parthiban,R. Balamurugan, D. and Jeyaprakash, B.G. 2015. Spray deposited $\mathrm{ZnO}$ and $\mathrm{Ga}$ doped $\mathrm{ZnO}$ based DSSC with bromophenol blue dye as sensitizer: Efficiency analysis through DFT approach. Elsevier. Materials Science in Semiconductor Processing. 31. 471-477.

Syafinar, R. Gomesh N. et al. 2015. Potential of Purple Cabbage, Coffe, Blueberry and Turmeric as Based Dyes for Dye Sensitized Solar Cell (DSSC). Elsevier. Energy Procedia. 79. 799-807.

Vigneswaran, N. Kumar, S. et al. 2006. Functional Finishing of Cotton Fabrics Using Zinc Oxide-Soluble Starch Nanocomposites. Nanotechnology. 17. 50-87.

Wang, Z. L. Kong, X. Y. and Zuo, J. M. 2003. Novel Nanostructures and Nanodevices of ZnO. Phys. Rev. Lett. 91, 185-502.

Williamson, G. K. and Hall, W. H. 1953. X-ray line broadening from filed aluminium and wolfram. Elsevier. Acta Metallurgica. 01.22-31.

Xian, F. and Li, X. 2012. Effect of Nd doping level on optical and structural properties of $\mathrm{ZnO}$ :Nd thin films synthesized by the sol-gel route. Elsevier. Optics \& Laser Technology. 45. 508512.

Yang, L. Tang, Y. et al. 2008. Raman scattering and luminescence study on arrays of $\mathrm{ZnO}$ doped with $\mathrm{Tb}^{\mathrm{at}}$. Physical Review B: Condensed Matter. 403. 2230-4.

Yuliarto, B. 2006. Teknologi Sel Surya untuk Energi Masa Depan, Majalah Iptek ISTECS. 6-8.

Zhao, Q. Xie, T., et al. 2007. Size and Orientation Dependet Photovoltaic Properties of $\mathrm{ZnO}$ Nanorods. J. Phys. Chem. 111. 17136-17145. 
THIS PAGE INTENTIONALLY LEFT BLANK 